\section{International Scientific Journal Theoretical \& Applied Science}

p-ISSN: 2308-4944 (print) ｅ-ISSN: 2409-0085 (online)

Year: 2017 Issue: 03 Volume: 47

Published: $30.03 .2017 \quad$ http://T-Science.org

SECTION 25. Technologies of materials for light and textile industry.
Victor Goldade

Dr. Sci. (Eng.), Professor,

V.A. Belyi Metal-Polymer Research Institute of National Academy of Sciences of Belarus;

Francisk Skorina Gomel State University,

Gomel, Belarus

victor.goldade@gmail.com

Nataly Vinidiktova

$\mathrm{PhD}$, Scientific researcher,

V.A. Belyi Metal-Polymer Research Institute of National Academy of Sciences of Belarus,

Gomel, Belarus

vns_lns@mail.ru

\title{
ANTIMICROBIAL FIBERS FOR TEXTILE CLOTHING AND MEDICINE: CURRENT STATE
}

\author{
Abstract: This article is a review devoted to polyester fibers with antimicrobial properties and includes the \\ description of antiseptic components of fibers, testing methods and fiber's properties. The final part is devoted to \\ application of antimicrobial fibers (as well as natural and synthetic ones) in medicine and clothing. \\ Key words: biodeterioration, antiseptic components, Triclosan, silver nanoparticles, antimicrobial activity, \\ properties and application. \\ Language: English \\ Citation: Goldade V, Vinidiktova N (2017) ANTIMICROBIAL FIBERS FOR TEXTILE CLOTHING AND \\ MEDICINE: CURRENT STATE. ISJ Theoretical \& Applied Science, 03 (47): 178-194. \\ Soi: http://s-o-i.org/1.1/TAS-03-47-27 Doi: crossef https://dx.doi.org/10.15863/TAS.2017.03.47.27
}

\section{INTRODUCTION}

Since ancient times the mankind uses fibrous materials for production of clothes, tools, as well as for medical purposes. For example, the use of fibers in medicine was first mentioned in 'Surgical Papyrus' nearly 4,000 years ago. In the Indian manuscript 'Susanta Sambita' written approximately 2,500 years ago, a variety of fibrous materials are mentioned such as horse hair, leather strips, cotton, animal sinews and fibrous tree bark. At present, textiles have found their way into a variety of medical applications. In addition to protective medical clothing, textiles in the form of fibers and fabrics are used as implants, filters and surgical dressings. Recent decades have witnessed major development in the production of medical textiles, as well as in materials and technologies used to manufacture them.

The global problem of technogenic deterioration of environmental conditions for life on the Earth have been considerably aggravated in the 21 st century. The problems of local reduction of detrimental effects of the changed environment on human beings and the sphere of their existence have become topical as never before.

In the system "human - textile product habitat", the textiles act as protection for a person. The new generation textile products which are produced taking into account the adverse changes in the ecological environment are actively minimizing their effect. Additional functional properties are being imparted to polyester fibers which are traditionally incorporated into the composition of practically all textile fabrics to increase their wearand crease-resistance. The best world samples of polyester fibers possess antimicrobial activity, ability to discharge static electricity, demonstrate the reduced combustibility and have other special properties. American, Chinese, Japanese and other textile products have appeared in the market which react "smartly" on the change of the parameters of the environment reducing its harmful effects on a human being. Targetedly modified polyester fibers are an indispensable component of such products.

Chemical fibers are obtained from products of chemical processing of natural polymers (artificial fibers) or from synthetic polymers (synthetic fibers). Despite continuous improvement of the textile production and advancement in technologies for chemical fibers, not so many methods to impart them with special properties are developed. Classical methods for filling and plasticization of the polymer base have long remained a sole instrument to regulate the chemical fiber properties. Currently, the targeted modification of the surface layer of fibers which does not affect their core has become the leading trend in the textile materials science. Such modification is implemented predominantly by the diffusion mechanism using the technological 
environments which are thermodynamically compatible with the polymer base of the fibers. The latter condition is a significant limitation to the range of technological impact on the surface layer structure, thus making it impossible to introduce a lot of very effective target modifiers into it.

As an alternative, production of multilayer fibers consisting of polymer core (which properties essentially determine the deformation-strength characteristics of the fiber) and one-two external layers which impart the fiber with special properties (wettability/non-wettability, frictionality/antifrictionality, high fusibility/low fusibility, etc.) has experienced active growth in many countries in the 1990s. However, interest in them quickly faded due to high costs of the considerably sophisticated industrial equipment, low stability of technological process of extrusion "facing" of the fibers, unreliability of multitubular extrusion heads and complexity of their repair.

The situation was radically changed at introduction of the methodology of surface modification of chemical fibers based on implementation of the crazing phenomenon. Crazing is a process of plastic deformation of polymers which brings them into a specific structural state. At loading levels and properties of the environment (which are individual for each material), special areas of the oriented state - crazes - occur in the specimen. These are microcracks which walls are connected by fibrils less than $10 \mathrm{~nm}$ in diameter. The extent of crazes opening in the polyester fibers (in glassy state at room temperature) subjected to orientational drawing in the surface-active liquid media which promote cracking of fibers provides for the possibility to introduce into the surface layer of the fiber any substances irrespective of their physicochemical nature. At first, crazing was used in the processes of water-repellent fibers dyeing, and in the 1980-90s - to produce semiconductor and lowcombustible chemical fibers.

Nevertheless, crazing has not found application yet in large-scale production of chemical fibers and is very seldom used in the technology for their processing. As a rule, basic methods for chemical fibers modification by the mechanism of crazing are know-how of the leading manufacturers of fibers with special properties which are closed to third-party experts.

\section{PROBLEM OF TEXTILE FABRICS BIODETERIORATION}

"Biodeterioration" is defined as the damage of materials, raw materials or products under the influence of biological factors [1] - microorganisms (bacteria, microfungi), insects (moths, khapra beetles, wood-boring beetles, termites, cockroaches) and mammals (rat and mice).
Materials biodeterioration can be classified into three main categories [2]: actual biodeterioration, biofouling, biological contamination.

Actual biodeterioration takes place by two mechanisms: 1) use of organic substances by microorganisms as the source of nutrients and energy (assimilation); 2) damage of materials caused by microbial products (destruction). Biofouling is the accumulation of aquatic organisms (bacteria, algae, sponges, etc.) on the surfaces of products. Biological contamination is the colonization of dust layers, mineral and organic matters on hard materials' surfaces by microorganisms.

Textile fabrics biodeterioration occurs at various stages of their life cycle: in the course of fiber preliminary processing at spinning, weaving and finishing stages due to high temperatures and humidity; during storage, transportation and operation when the standard conditions are not met. Most of the damage caused to textile fibers occurs due to putrefactive bacteria (Bacillus, Pseudomonas, Bacterium) and mold fungi (Aspergillus, Penicillium, Trichoderma). The deteriorating effect of bacteria is due to their ability to use practically any nitrogen- and carboncontaining sources of energy and nutrients of organic and inorganic origin [3]. Biodeterioration caused by mold fungi takes place due to stress rupture of the product surface layer by the expanding mycelium in combination with biochemical enzymatic effect. Characteristic features of biodeterioration are fabric discoloration and sheen, appearance of spots with putrefactive smell, decrease in acid- and alkali resistance and strength characteristics, loss of weight, damage of surface layer and fibers stratification [4]. Mechanisms of textile fibers biodeterioration are determined by their origin and chemical composition.

Natural fibers are the most affected by the adverse effects of biodeterioration. Destroying agents are proteolytic enzymes (i.e. the ones that catalyze the breakdown of proteins) produced by microorganisms. Biodeterioration of wool fiber protein basis starts at $\mathrm{pH}$ 8.5. Ammonia accumulation in fibers leads to $\mathrm{pH}$ increase, following which alkaline enzymes that are actively destroying fibers come into action [5]. Self-heating of insufficiently dry cotton and wool in the pile occurs due to intensive development of microorganisms in them. Heat energy is released when organic compounds of fibers are oxidized by waste products of aerobic bacteria. Microbiological stability of wool fibers is higher than that of cotton. Deterioration of wool takes place at a higher moisture content in it (over $24 \%$ ) whereas development of microorganisms on cotton starts at 9 $\%$ [6].

Process of synthetic fibers biodeterioration starts with adsorption of microorganisms on them. Their metabolites (intermediate products of 
metabolism) are diffused into the fiber micropores and cracks. Process of biological degradation is facilitated by availability of functional groups in macromolecules, weak orderliness of supramolecular structures, low degree of polymer material crystallinity. Therefore, fibers based on heterochain polymers - polyether, polyamide, etc. - are less bioresistant. Bacterium and fungus colonies occur on lavsan on the 30th day when kept in the active microbial environment. Carbochain polymer based fibers (chlorin and ftorlon) are more resistant to microbiological damages [7].

Methods of textile material protection against biodeterioration are applicable at the stages of textile products handling and consumption, as well as in their manufacturing process. [7]:

The first group contains the following methods

- creation of temperature and humidity conditions for products storage and transportation under which the microorganisms lose their ability to reproduce $\left(T=12 \div 18 \quad{ }^{\circ} \mathrm{C}\right.$, humidity $50 \div 70 \%$ );

- short-term exposure to radiation and UV-rays;

- purification of the air inside the warehouse;

- using ultrasound for product processing;

- airtight packaging;

- textile products dry cleaning and washing using disinfectants.

Since these methods do not produce a long-term effect, antiseptic properties are imparted to textile materials in the manufacturing process. Antimicrobial activity of synthetic fibers is created using three groups of methods:

1) Composite methods of modification [8]: polymer granulate processing with metal cations; introduction of bactericide agents into the melt or solution of fiber-forming polymeric compound;

2) Methods of surface modification [9]: impregnation of fibers and threads with bactericides; imparting antimicrobial properties to textile materials in the process of their dyeing and final finishing; target impregnation of fabrics, knitted goods, nonwoven fabrics with solutions of antimicrobial preparations; hydrophobization of fibers' and threads' surface; crazing technology by introducing antiseptic substances into the crazes;

3) Crazing technology by introducing antiseptic substances into the crazes on the fiber's surface [10].

\section{FIBERS}

\section{ANTISEPTIC COMPONENTS OF}

Antiseptic additives to synthetic fibers shall meet two basic requirements: suppression of growth of microorganisms and safety to human health. Various additional aspects of the production schedules defining technological effectiveness and consumer properties of textile products make it more difficult to meet these requirements.

The antimicrobial substances used in chemical industry are usually classified according to three criteria: 1) origin and chemical composition, 2) mechanism of action against microorganisms, 3) spectrum of action.

$$
\text { By origin and chemical }
$$
composition, antimicrobial components are divided into [11]:

inorganic substances (silver, calcium, magnesium, copper compounds);

organic compounds (nitrofuran class derivatives; benzene derivatives; 8-Oxyquinolines; sulfonamide compounds; aldehydes; organic acids and their salts; surface-active substances (SAS) and compositions on their base;

bioorganic substances which are created by processing bacteria, fungi, plants or their waste products (antibiotics).

By mechanism of action against microorganisms, the following substances are distinguished [12]:

-bactericidal, i.e. the ones that kill microorganisms;

-bacteriostatic, i.e. the ones that inhibit their reproduction.

B y efficiency of impact on various classes of microorganisms, antimicrobial substances are divided into groups which spectrum of action can be defined as [13]:

broad spectrum, if antimicrobial substances kill or inhibit a wide range of Grampositive and Gram-negative bacteria (in 1884 Danish microbiologist $H$. Gram developed a method for differentiating bacteria: when stained (using the method proposed by him) cells of one type of bacteria - Gram-positive ones - get colored, while cells of other bacteria - Gram-negative ones - are decolorized);

limited spectrum, if they are effective against certain types of Gram-positive and Gramnegative bacteria or bacteria and fungi;

narrow spectrum, if antimicrobial substances are active against representatives of a relatively small number of taxons of microorganisms, for example, against Gram-positive or Gramnegative bacteria.

Characteristics and a list of basic groups of antimicrobial substances used in the commodity production are given below.

\subsection{Silver-based colloidal systems}

Silver is the most active antiseptic agent among metals [14-16]. It's no secret that silver has been used to combat bacteria throughout history. The earliest records show that in ancient days, silver was used to 
line water vessels during long sea-going voyages. In the middle ages, Church made its chalices and Eucharist trays of silver to prevent the spread of disease. Although some other metals, such as copper, zinc and cobalt, have attracted attention as effective antimicrobial agents for textiles, silver is by far the most widely used in general textiles as well as in wound dressings.

For about a thousand years, silver is known to be a very efficient agent against infection. However, only application of nanotechnology made it possible to obtain a long lasting antimicrobial effect by means of silver compounds. The reason for this is as follows. Silver (in the form of metal blocks) deliver $\mathrm{Ag}^{+}$ions to the environment in insignificant quantities while soluble silver salts are strong antiseptic agents which act, however, for a very short period of time. Silver particles with sizes between 10-30 nm provide for optimum ratio between antimicrobial activity and antiseptic effect duration.

Silver, as compared to other disinfecting preparations, has the following advantages:

$\square$ broad spectrum of action covering about 600 microorganisms (the majority of antiseptic agents and antibiotics are active against no more than 20 microorganisms), $5 \cdot 10^{-5} \mathrm{~g} / \mathrm{l}$,

$\square$ high activity at low concentrations of about $\square$ harmless to humans and warm-blooded

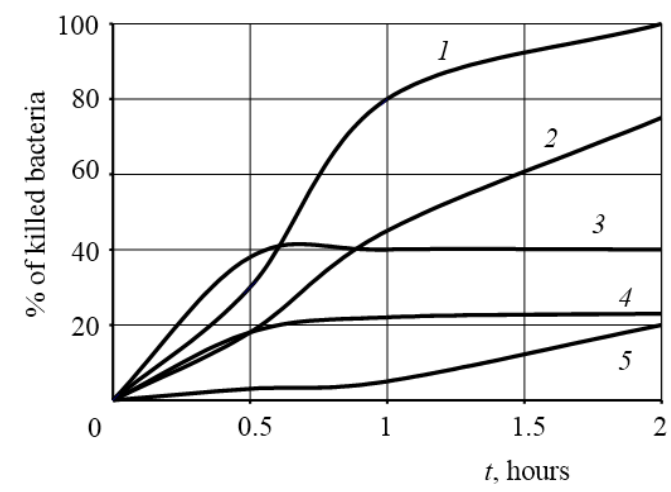

$a$

animals,

$\square$ long-lasting antiseptic action.

Silver biological activity pertains to the fact that $\mathrm{Ag}^{+}$ions, firstly, connect to the membrane proteins of microorganisms thus disturbing the membranes' function, and, secondly, produce solid complexes with DNA nucleotides as a result of which DNA helical structure is broken. Both of these factors stop bacteria from reproducing.

The kinetics of microbes dying off under the antiseptic agent influence is one of its key characteristics. Die-off rate of E.Coli bacteria (colibacillus) under the influence of silver ions depends on ion concentration. So, at a concentration of $1 \mathrm{mg} / \mathrm{l}$ the colibacillus is killed in $3 \mathrm{~min}$., at a concentration of $0.5 \mathrm{mg} / \mathrm{l}$ - in $20 \mathrm{~min}$., and at a concentration of $0.2 \mathrm{mg} / \mathrm{l}$ - in $50 \mathrm{~min}$. At a concentration of $0.05 \mathrm{mg} / \mathrm{l}$ it takes two hours to obtain complete bactericidal effect [13].

Effect of silver salts solutions is 1750 times stronger than that of carbolic acid with the same concentration, and 3.5 times stronger that that of corrosive sublimate. According to [14], antimicrobial action of silver ions is stronger than that of chlorine, chlorinated lime, sodium hypochlorite and other strong oxidizers with the same concentration. Comparative data of disinfecting preparations are presented in Fig. 1 as dependences of the number of the killed bacteria versus time of contact $t$.

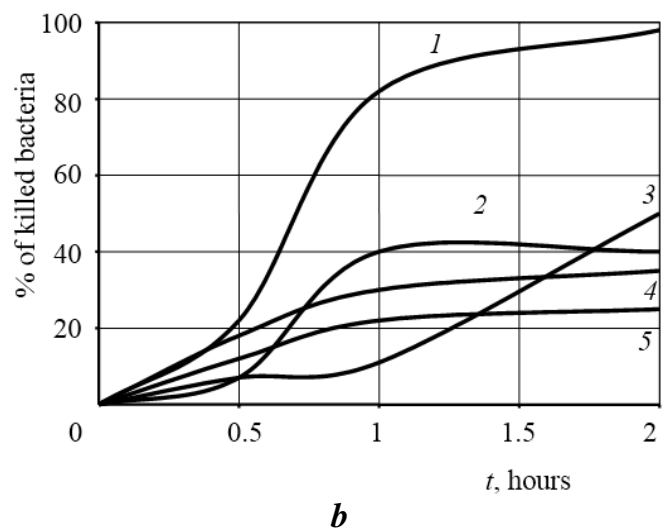

Figure 1 - Comparison of bactericidal action of some disinfectants against colibacillus (a) and fecal bacteria Str. Faecalis (b): 1- silver water; 2 - ammargen; 3 - phenol; 4 - chlorine; 5 - chlorinated lime. Reagent concentration $1 \mathrm{mg} / \mathrm{l}$, temperature $7{ }^{\circ} \mathrm{C}[14]$

E. Coli bacteria are more sensitive to silver ions action than Str. Faecalis. Complete inactivation (loss of activity) of Str. Faecalis bacteria in water with concentration of $10^{4}$ species/l occurs after $3 \div 4$ hours of contact with silver solution $(0.2 \mathrm{mg} / \mathrm{l})$, while one hour is enough to suppress $E$. Coli under the same conditions [15].

Besides the listed bacteria, causative agents of typhus, olm, salmonella, chromobacteria, vibrioes, causative agents of diphtheria and other dangerous microorganisms are killed rather quickly under the influence of silver ions. It is characteristic that newly identified strains are more resistant than the old ones which are stored in a laboratory. Silver does not kill spore-forming bacteria, but spore germination in the presence of silver ions is delayed. Gram-negative bacteria are more sensitive to silver than the Grampositive ones. Yeast and yeast-like fungi are poorly 
suppressed by silver. Silver has no effect on mold fungi [17]. As a rule, pathogenic (disease-producing) microorganisms are more sensitive to silver than saprophytes (organisms that feed on organic substance of dead material). Silver solution with concentration of $0.5 \mathrm{mg} / \mathrm{l}$ at temperature of $37{ }^{\circ} \mathrm{C}$ and time of contact of 1-2 days deprives bacteriophages (bacterial viruses) of life.

Temperature increase reduces resistance (endurance) of microorganisms to silver. These data are well agreed with the ideas on silver effect upon bacterial enzyme systems: enzymes activity decreases as temperature increases and they are easier inactivated by inhibitors.

The bactericidal effect of silver is higher at alkaline values of $\mathrm{pH}$ environment. Thus, test experiments showed (at $\mathrm{pH}=8 \div 9$ ) a significant growth in $E$. coli bacteria, while the growth of microbes was not registered after 30 minutes of bacteria contact with $0.2 \mathrm{mg} / \mathrm{l}$ silver solution. At $\mathrm{pH}$ $<7$, silver has no noticeable bactericidal effect on collibacillus [18].

For synthetic fibers, silver particles can be incorporated into the polymer before extrusion or before nanofiber formation using electro spinning. The treatment of natural fibers with metals can only be undertaken at the finishing stage and various strategies have been devised to enhance the uptake and durability. Cotton has been pretreated with succinic acid anhydride, which acted as ligand for metal ions to enhance the subsequent adsorption of metallic salts $\left(\mathrm{Ag}^{+}\right.$and $\left.\mathrm{Cu}^{2+}\right)$ and to provide very effective antibacterial activity.

Concerning the studies of fiber/silver nanocomposites, most researches have been interest in preparations of ultrafine fiber containing silver nanoparticles. Surface modification of cotton microfibers with silver nanoparticles can increase both the price and purpose of the fibers. [19]. For example, today, AgION Technologies, a Nexera trusted technology partner is using its patented silver based antimicrobial compound to control destructive microbes for use in medical applications, food packaging and more. And now, the same silver based technology incorporated into the Nexera's SpectraShield-9900 Series of respirator masks can provide protection from these microbes [20].

The materials impregnated with silver salt solutions (silvered water, silver citrate or lactate, as well as silver chloride) promote wound healing and prevent its suppuration. However, practical application of silver is not feasible in view of its high cost. Besides, direct sunlight causes the decomposition of silver salts resulting in discoloration of the material [21].

\subsection{Organic antimicrobial substances}

At the current stage of polymer products manufacture, organic antimicrobial substances are becoming more effective than inorganic ones thereby forcing the latter out of the market. By chemical nature, the following groups of antimicrobial additives used in polymer materials are distinguished $[22,23]$.

Aldehydes, organic acids and their derivatives. Salicylanilid is a colorless and odorless crystal powder; soluble in alcohols, ethers, benzene; poorly soluble in water; $T_{m} \approx 136 \div 138{ }^{\circ} \mathrm{C}$; used as a fungicide (agent that destroys or suppresses pathogenic fungi) for non-metallic materials and as an antiseptic agent in production of film materials and artificial leather. Methoxyacetaldehyde, which is used as the antimicrobial plastics modifier, is soluble in water, alcohol, acetone, less soluble in ether; possesses sweet taste; $T_{b}=92.3^{\circ} \mathrm{C}$. Benzoic acid is a white crystal powder having a characteristic odor; poorly soluble in water, freely soluble in alcohol, ether, benzene; $T_{m}=122.3{ }^{\circ} \mathrm{C}, T_{b}=249.2{ }^{\circ} \mathrm{C}$; it is an antiseptic and preservative agent used in production of dyes, medicines, fragrances. Sodium benzoate has long been known as a preservative agent, stabilizer for polymers and corrosion inhibitor; it is a crystal powder that is soluble in water and alcohol. Copper naphthenate (technical product) is a greenish-blue pasty substance; insoluble in water; marginally soluble in organic solvents; fungicide, antiseptic agent for wood, ropes, fabrics. Magnesium acetate is a crystal substance; soluble in water, methanol; $T_{m}=$ $323^{\circ} \mathrm{C}$ (with decomposition); deodorizing, antiseptic and disinfecting agent; main field of application: disposable non-woven products (napkins, towels).

$$
\text { SAS and S A S - b a sed }
$$
compositions. Cationic antimicrobial agent Katamin $A B$ is a colorless or yellow transparent liquid; soluble in water; used to disinfect fabrics, surfaces of metal and wooden products; can be introduced into the cement mix. Altosan $M B$ is a transparent colorless liquid; soluble in water; used as a bactericide, de-emulsification agent and corrosion inhibitor; it has a wide range of antimicrobial activities. Katapins are brown liquids or salvy substances; soluble in water, alcohols, benzene; insoluble in ethers; used as corrosion inhibitors, broad-spectrum antimicrobial agents, wetting agents, emulsifiers.

Compound ethers, phenols and their derivatives. The most common parabens (paraben acid derivatives) are methylparaben and propylparaben - white or yellowish crystal substances with slight specific ("phenolic") odor; they are soluble in alcohols, partially soluble - in water; they are used as preservatives in cosmetics [24]. Triclosan - white color powder with slight pleasant odor; poorly soluble in water, freely soluble in alcohols, organic solvents; $T_{m} \approx 55-60{ }^{\circ} \mathrm{C}$, is used as a broad-spectrum antimicrobial component for a large number of cosmetics and perfumery products [25]. 
Other antimicrobial substances. In the last decades, a new class of substances water-soluble polymers (polyguanidines) with broadrange and stability of antimicrobial action and low toxicity - has occupied its niche within the biocides market [26]. Metacide - salvy substance of light yellow color, odorless, soluble in water and organic solvents - is a typical representative of substances of this class. It is used to impart antimicrobial activity to genuine leather, paint coatings and products made of polymer materials. Polyguanidines are a part of antiseptic agents allowed for household use (Inkrasept). Copper 8-oxyquinolate (Cuprocin) is used to protect fabrics, paper, wood, paints and plastics against microbial damage.

According to hygienic classification, all listed antimicrobial substances are related to Class 3 (moderately hazardous) and Class 4 (slightly hazardous). For example, $\mathrm{LD}_{50}$ indicator (lethal dose which causes the death of $50 \%$ of a group of test animals, in grams per kilogram of animal body weight) for methyl- and propylparabens is about 8 $\mathrm{g} / \mathrm{kg}$; benzoic acid - $1.7 \mathrm{~g} / \mathrm{kg}$; salicylic acid - 0.89 $\mathrm{g} / \mathrm{kg}$ [24]; thriclosan - $4.3 \mathrm{~g} / \mathrm{kg}$; values for polyguanidines are within the range 0.2 to $0.4 \mathrm{~g} / \mathrm{kg}$ [18].

The analysis of the list of antimicrobial agents used by modern industry has led to the following conclusion. Triclosan and colloidal silver solutions are best suitable for use (by criteria of antimicrobial activity, safety to human health and technological effectiveness) as basic biocides for PET fibers modification using the crazing technology. Development of modifying compounds based on these substances is addressed in the following paragraphs.

\subsection{Modifying compounds based on Triclosan}

Triclosan is a substituted diphenyl ether, to be more precise, 2.4.4-trichlor-2-hydroxydiphenyl ether with the molecular weight of 289.5. Its structural formula is<smiles>Oc1cc(Cl)ccc1Oc1ccc(Cl)cc1Cl</smiles>

Triclosan (Tr) was developed in the 1960s as a broad-spectrum antibacterial agent. Its developer Ciba-Geigy company - has become its main supplier to the world market. At first, Tr was believed to be a nonspecific antiseptic agent destroying any cells. Soon it has been established that $\operatorname{Tr}$ has a selective effect on microorganisms by primarily suppressing prokaryotes - bacteria that lack a membrane-bound nucleus and typical chromosomal apparatus. The majority of pathogenic bacteria are prokaryotes. 20 years of clinical tests and accumulation of facts have led to conclusion that $\mathrm{Tr}$ is effective in small doses, has a broad spectrum of action and no negative effects on human health and the environment which favorably distinguishes it from the majority of antimicrobial agents [27].

$\operatorname{Tr}$ has a wide range of action against gramnegative and gram positive bacteria. This compound, owing to the presence of the acaricide benzyl benzoate, also offers protection against mites and is used in acaricide (spray or powder) formulas, as well as in a solution ( $25 \%$ concentration) for the treatment of scabies. This compound is nontoxic. Benzyl benzoate is an acaricide that acts, chemically, directly on the mites. Due to its antibacterial properties, Triclosan has found widespread use in a variety of consumer products including toothpastes, deodorants, soaps, polymers and fibers [28].

According to the data provided by of F.F. Erisman Federal Scientific Center of Hygiene (Table 1) $\operatorname{Tr}$ is active against the majority of pathogenic microorganisms settling on the skin's surface [25].

\section{Microorganisms which growth is suppressed by Triclosan}

Table 1

\begin{tabular}{|l|l|l|}
\hline \multicolumn{1}{|c|}{ Gram-positive bacteria } & \multicolumn{1}{|c|}{ Gram-negative bacteria } & \multicolumn{1}{|c|}{ Fungi and yeast microorganisms } \\
\hline Staphylococcus aureus & Esherichia coli & Candida albicans \\
Staphylococcus epidermidis & Enterobacter cloacal & Epidermophyton flocssum \\
Streptococcus pyogenes & Enterobacter aerogenes & Trichophyton entagrophytes \\
Propionibacterium acnes & Klebsiella pneumonial & Tricophyton rumbum \\
Clotridium tetani & Proteus vulgaris & \\
Corynebacterium species & Proteus mirabilis & \\
Salmonella paratyphi A, B & & \\
Salmonella choeraesuis & & \\
Shigella flexneri & & \\
Shigella dysenterial & & \\
Vibrio choleral & & \\
\hline
\end{tabular}

Tr importance as a broad-spectrum antibacterial

agent is confirmed by the practice of intrahospital 
infections suppression with its help [29]. Besides, Tr has anti-inflammatory effect [30] by blocking synthesis of inflammatory mediators in fibroblasts (main cellular form of connective tissue) and suppressing the eukaryotic cells which initiate inflammation.

Thus, the safety criterion has become a primary argument in selecting $\operatorname{Tr}$ (given other conditions being equal) as the antimicrobial component for PET fibers. Tr biocompatibility is confirmed by the results of numerous laboratory, toxicological and long-term clinical trials.

The main problem of Triclosan introduction into the crazes of the fibers is considerable viscosity of its solutions and their poor wetting of PET fibers. Attempts to overcome this challenge by $\mathrm{Tr}$ dissolution in alcohols and other organic solvents result in occurrence of many other problems. It seemed like an optimum solution to substitute $\operatorname{Tr}$ true solutions with its aqueous suspensions. Water is much cheaper than solvents being irrecoverably lost in the production process, is compatible with PET fibers oiling agents and is environmentally safe. Actually, the development of stable surface-active $\mathrm{Tr}$ aqueous suspensions has determined competitiveness of antimicrobial PET fibers obtained by the mechanism of crazing.

$\mathrm{Tr}$ water emulsions were prepared using the surface-active components to stabilize the thermodynamically unstable suspension of $\mathrm{Tr}$ microdrops in water. It seemed feasible to use for this purpose the substances which are part of the process liquids ensuring the oiling effect at PET fibers processing.

Sintezin was the first investigated substance of this group. The main characteristics of sintezin 41-82 - commercial product purchased by chemical industry enterprises - are presented in Table 2.

Sintezin 41-82 technical data

Table 2

\begin{tabular}{|l|c|}
\hline \multicolumn{1}{|c|}{ Parameter description } & Value \\
\hline Appearance & White color paste \\
\hline Water content, \% by mass, no more than & $42-46$ \\
\hline pH of an aqueous solution of 10\% by mass & $7.5-8.5$ \\
\hline
\end{tabular}

The modifying emulsion preparation process consists of three operations: 1) $\operatorname{Tr}$ dissolving in alcohol; 2) preparing the sintezin aqueous solution mixing the sintezin in $1 / 3$ of the total amount of water, heating the mix to $50{ }^{\circ} \mathrm{C}$, adding the remaining water while stirring; 3 ) mixing the first and second solutions using a high-speed mixer. A suspension with the smallest particles (diameter $\sim 1$ $\mathrm{mcm}$, determined by an optical microscope) is received when using the following ratio of components, $\%$ by mass: $\operatorname{Tr}-1$, sintezin -1 , ethyl alcohol -30 , distilled water -68 .

The emulsion thus obtained has a pronounced antimicrobial activity. At microbiological testing, a zone (7-8 mm wide) of suppression of growth of microorganisms being tested is formed around the emulsion drop specimen on an agar plate (Fig. 2).

In the course of bench tests, an essential drawback of such modifiers was revealed: stratification of the mix and settling out of crystals occur in approximately $5 \mathrm{~h}$ after preparation of the solution. It is conceivable that stratification is caused by physical and chemical bonding of alcohol and Sintezin molecules resulting in depletion of $\mathrm{Tr}$ solution with solvent.

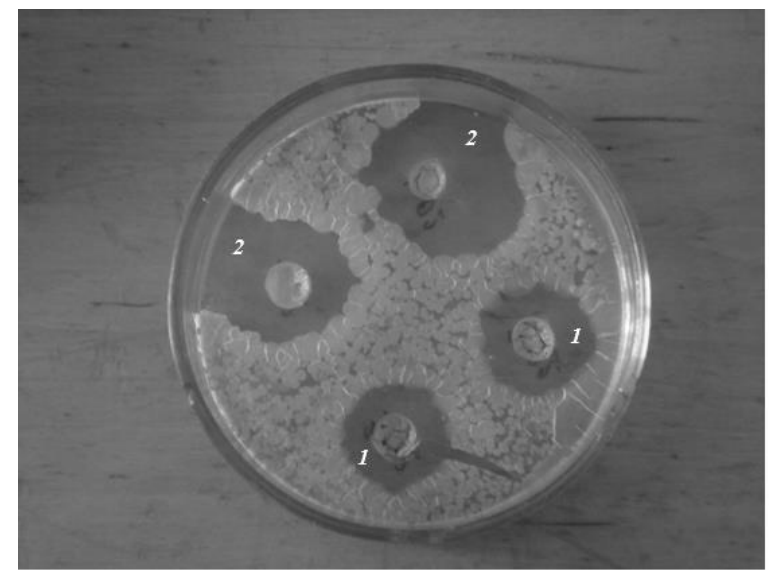

Figure 2 - Petri cup inhabited with Staphylococcus-type bacteria with antimicrobial emulsion samples: 1 - with sintezin, 2 - with sintanol. 
Sintanol is SAS used in standard compositions of oiling agents for PET fibers (individually or in the mix with sintezin). Sintanol DC-10 manufactured by Hoechst (Germany) is a mix of polyethylene glycol monoalkyl ethers based on primary fatty alcohols $\mathrm{C}_{n} \mathrm{H}_{2 n+1} \mathrm{O}\left(\mathrm{C}_{2} \mathrm{H}_{4} \mathrm{O}\right)_{m} \mathrm{H}$, where $n=10 \div 18, m=8 \div 10$. Experiments on $\mathrm{Tr}$ water emulsions preparation using this substance were held by controlling IR spectra of the received products. They give evidence of physical and chemical interaction between emulsion components which, most likely, results in Tr microdrops stabilization by creating (on their surface) a structural and mechanical barrier against nonionic molecules of Sintanol [31]. Particles of such microemulsion are characterized by a very low surface tension at the boundary of water [26]. The following composition of $\mathrm{Tr}$ emulsion $[32,33], \%$ by mass, has been developed to implement the crazing technology for obtaining antimicrobial PET fibers:

Triclosan $-0.8 \div 1.0$,

Sintanol $-3.0 \div 4.0$,

distilled water $-95.0 \div 96.2$.

Neonol is another surface-active component of oiling agents for polyether fibers. It is a polyethylene glycol monoalkyl ether based on secondary fatty alcohols $\left(\mathrm{C}_{n} \mathrm{H}_{2 n+1}\right)\left(\mathrm{C}_{m} \mathrm{H}_{2 m+1}\right) \mathrm{CHO}\left(\mathrm{C}_{2} \mathrm{H}_{4} \mathrm{O}\right)_{p} \mathrm{H}$, where $n+m=10 \div 20, p=12$. A modifying compound for PET fibers was prepared using Neonol aqueous solution in which $\operatorname{Tr}$ is dissolved. Optimum compound composition, $\%$ by mass, is as follows: $\mathrm{Tr}$ $1.0 \div 1.5$; Neonol 3.0; distilled water $95.5 \div 96.0$. This compound is surface active and PET fibers drawing in it is accompanied with intensive crazes formation. Crazes are filled with the liquid phase which retains antimicrobial activity inherent to $\operatorname{Tr}$ [34].

In conclusion, it should be noted that the optimum area of Triclosan utilization in the crazing technologies for synthetic fibers modification is the creation of its emulsions in aqueous environments possessing surface activity.

\subsection{Modifying compounds containing silver and bimetallic particles}

Introduction of silver and compounds based thereof to the fibers' structure, results, along with clear benefits (bactericidal action, lack of skin irritant effects, long-term antimicrobial effect), in significant increase in the price of fibers (cost of precious metal additives is added to the fibers price). Expediency of, firstly, modifying the fibers' surface layer only to avoid "trapping" of silver particles in polymer matrix, and, secondly, using colloidal, preferably nanodimensional silver particles, in the modifying compounds to maximize area of their contact with the microbial environment is evident. These problems can be rather simply solved by introduction of silver to the fibers structure by the mechanism of crazing [10].

Antiseptic compounds for fibers processing should address the following issues. Firstly, acceptable balance between the basic level of the modifying fibers antibacterial activity and duration of their antiseptic action shall be ensured. Secondly, mandatory retention of antimicrobial effect when washing the modified-fibers-containing textile products shall be ensured. These requirements are inconsistent and therefore creation of antiseptic compositions demanded the structure optimization and development of non-standard methods for their preparation. It is obvious that fibers with high silver ions concentration on the surface will have the greatest antiseptic activity. However, in this case the duration of silver action is small as ions of metal will leave the fiber surface layer within a relatively short service life of a textile product.

Optimization of the structure and mechanism of action of a silver-containing modifier of fibers by the "activity/duration of action" criterion can be carried out observing several technological principles, the most significant of which are the following.

1) Use of silver particles in colloidal or nanodimensional range [35]. [36].

2) Use of slightly soluble antiseptic compounds

3) Immobilization (fixation) of silver ions by the fibers polymer matrix containing functional groups which bind the ions [37].

When applying technologies envisaging the use of precious metals, the problem of reducing the consumption of the latter is always of crucial importance. A task was set to reduce silver concentration in the modifying compound by adding another, cheaper metal which creates antiseptic effect. It was solved by cultivation of colloidal copper particles on which surface the nanodimensional silver particles are settled.

The methodology of obtaining modifying compounds with bimetallic particles is as follows. When a colloidal copper solution is added to the silver nitrate solution, copper particles serve as a silver ions reducer by the exchange reaction mechanism

$$
2 \mathrm{Ag}^{+}+\mathrm{Cu}=\mathrm{Ag}+\mathrm{Cu}^{2+} \text {. }
$$

Bimetallic particles demonstrate complex antiseptic action: silver - against fungi, bacteria and viruses; copper - predominantly against fungi, especially mold ones. Exchange reaction of ions reduction prevents formation of silver dendrites as the growth of silver particles is localized at the centers of reduction and is limited by the size of colloidal copper particles.

The method of obtaining a modifying compound with bimetallic particles from the mix of silver nitrate and copper acetate $\mathrm{Cu}\left(\mathrm{NO}_{3}\right)_{2} \cdot 3 \mathrm{H}_{2} \mathrm{O}$ aqueous solutions was offered [38, 39].

By means of the instrument [40] it is established that all compounds mentioned in these paragraphs initiate crazes formation. 


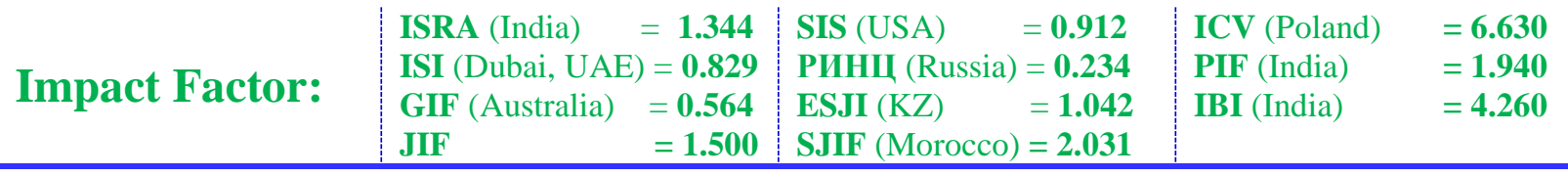

\section{FIBERS}

3. ANTIMICROBIAL ACTIVITY OF

Efficiency of the developed compounds as the technological medium which imparts antiseptic properties to polyether fibers is assessed by processing the fibers by the mechanism of crazing. Experimental samples of antiseptic fibers were subjected to microbiological trials.

Bactericidal and bacteriostatic fibers were manufactured as a part of the pilot batch. Bactericidal fibers (from bacterium and the Latin caedo, meaning, "I kill") are fibers that are capable of killing bacteria, and bacteriostatic fibers (from bacterium and Greek statis) do not upset the balance of bacteria on the skin, but temporarily stop bacteria from reproducing.

Bactericidal fibers were obtained by using the modifying compound with Triclosan and sintanol. The composition was prepared as follows [32]: sintanol was diluted upon stirring in a small volume of water warmed up to $50{ }^{\circ} \mathrm{C}$, triclosan batches were being added and the solution was being diluted with the remaining water. Bactericidal fibers production was carried out at the bundle speed of $16.1 \mathrm{~m} / \mathrm{min}$ and draw ratio of $210 \%$, temperature of the modifying compound amounted to $28{ }^{\circ} \mathrm{C}$.

Bacteriostatic fibers were processed with the compound based on triclosan and sintanol in which the triclosan concentration was reduced twofold and a solution of colloidal silver (Adjetta trade mark) in the amount of $4 \%$ by mass was additionally introduced. The composition was prepared similarly to the previous one, then the Adjetta solution was being added in batches to the mix. Fibers of the pilot batch were manufactured with speed of $13.6 \mathrm{~m} / \mathrm{min}$, draw ratio of $230 \%$, modifier temperature of $26{ }^{\circ} \mathrm{C}$.

The standard methods for assessment of the textile fibers antimicrobial effect are developed in many countries. The fibers antiseptic properties were determined using the methodology which summarized the essential features of similar purpose standards - AATCC 100-1993 (USA), SN 1959241983 (Switzerland), JIS 1902-1998 (Japan).

Cultures of microorganisms were sowed in Petri cups with the agarized nutritive medium. A sample of modified fibers $(\sim 0.03 \mathrm{~g})$ was placed into the cup. The cups with samples were kept in a thermostat at temperature of $29 \pm 2{ }^{\circ} \mathrm{C}$ and relative humidity in air of $90 \%$ during 14 days. Width $h$ of a zone of suppression of bacterial growth around the sample was registered according to the Russian State Standard (GOST) 9.802-84. The basics of the method are explained in Fig.3 where it can be seen that the biofilm of testing bacteria St. ep. has grown to the edges of the sample from the initial PET fibers (a), but has not entered the zones of bacterial growth suppression which are forming round the fibers and which had been processed by the colloidal silver solution $(b)$ and Triclosan $(c)$.

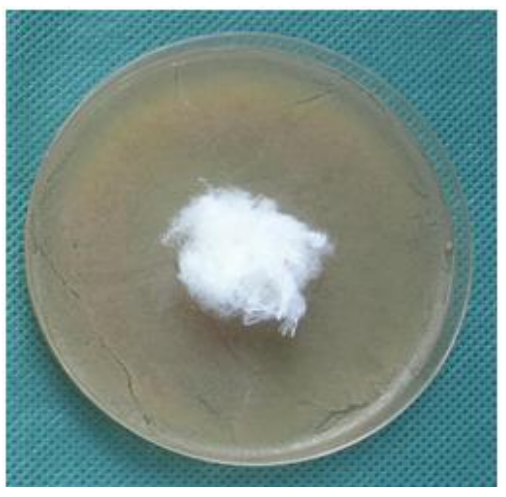

a

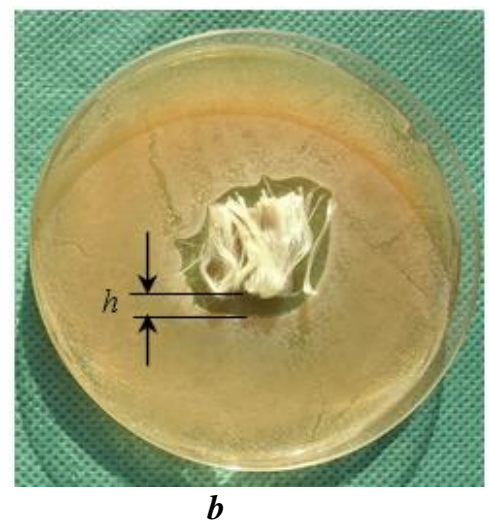

$\boldsymbol{b}$

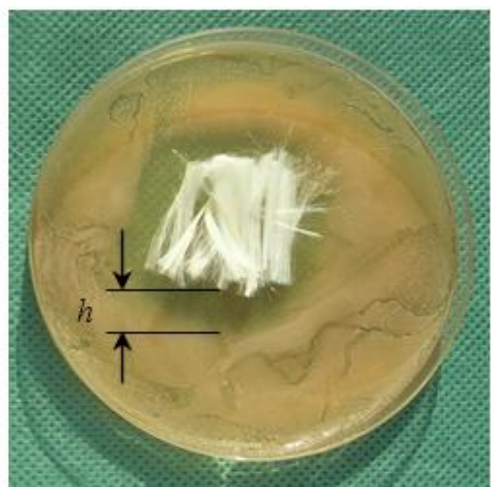

$\boldsymbol{c}$

\section{Figure 3 - Suppression of growth of testing bacteria St. ep. by PET fibers: $a$ - initial fibers, $b$ and $c-$} modified by compounds containing silver [36] and Triclosan [33], $h$ - width of suppression zone.

In the course of heat and wet processing, the fibers lose their ability to suppress vital functions of microorganisms. Stability of antiseptic characteristics of the modified fibers was estimated by subjecting them to repeated processing according to the method described in [41]. The fiber sample was placed into a beaker with a washing solution ( $5 \mathrm{~g}$ of detergent per 11 of water) heated to $T=45^{\circ} \mathrm{C}$., The sample was brought into rotation with frequency of $50 \pm 5 \mathrm{rpm}$ during 5 minutes using a magnetic stirrer, then it was rinsed under running water $(1 \mathrm{~min}$.) and left at room temperature until dry. This processing corresponds to soft conditions (method 7B) of textiles washing in the activator-type machines [42]. Antimicrobial activity of fibers and fabric samples was controlled after each washing.

In the course of crazing modification, PET fibers and products thereof acquire a stable property 
of suppressing growth of pathogenic microflora on the human body and its environment. In the textile technology, PET fibers are used in the mix with cotton, woolen, silk and other fibers. It allows to regulate antimicrobial activity of textiles by varying the share of antimicrobial fibers in the mix. At the same time, antimicrobial fibers retain the strength and anti-friction properties inherent to PET and make the textile fabrics crease-resistant. The results of assessment of these properties of PET fibers modified by the crazing mechanism and textile materials based on them are shown below.

Experimental samples of PET fibers processed with different antiseptic compounds demonstrate antimicrobial activity which indicators are shown in Table 3 [43].

\section{Antiseptic indicators of the modified PET fibers}

Table 3

\begin{tabular}{|l|c|c|c|c|c|c|c|}
\hline \multirow{2}{*}{ Indicator } & \multicolumn{7}{|c|}{$h(\mathrm{~mm})$ after heat and wet processing (cycles) } \\
\cline { 3 - 8 } Modifier & 0 & 10 & 20 & 30 & 40 & 50 & 60 \\
\hline Althosan solution concentration (\%): & & & & & & & \\
10 & $7-9$ & $\geq 1$ & 0 & - & - & - & - \\
50 & $8-10$ & $\geq 1$ & 0 & - & - & - & - \\
\hline Kathamin solution concentration (\%): & & & & & & & \\
10 & $5-7$ & $\geq 1$ & 0 & - & - & - & - \\
50 & $9-10$ & $\geq 1$ & 0 & - & - & - & - \\
\hline Compound based on Triclosan [28] & $9-13$ & $8-12$ & $7-11$ & $6-9$ & $4-8$ & $3-6$ & $2-5$ \\
\hline Compound based on silver [35] & $3-5$ & $3-4$ & $2-4$ & $2-3$ & $1-2$ & $1-2$ & 0 \\
\hline
\end{tabular}

The following conclusions can be drawn based on comparison of these data. Kathamin and Althosan aqueous solutions are intensively removed from the crazes during heat and wet processing of fibers, while the removal rate has little dependence on the solution concentration. Colloidal silver particles trapped in the crazes "work" long enough. Triclosan is not washed away from the crazes even after 60 fiber processing cycles. It might be considered that the colloidal silver particles and Triclosan introduced into PET fibers by the crazing mechanism meet the requirements imposed by the textile industry on the new generation fibers for manufacturing products for personal use and special purposes [44]. Antimicrobial activity of the fibers containing colloidal bimetallic $(\mathrm{Cu}-\mathrm{Ag})$ particles is higher than that of fibers containing silver particles and is comparable with the indicators of activity of fibers modified by Triclosan. The mass of active components of antimicrobial compounds trapped by the crazes is within $0.9 \div 3.3 \%$ of the mass of initial fibers [45].

Technological effectiveness and assortment possibilities of the cotton yarns with introduction of $30 \div 50 \%$ of antimicrobial PET fibers have been positively evaluated [46].

Microbiological testing of fabrics with different content of antimicrobial fibers was performed in the accredited laboratory "Scientific Research Institute of Epidemiology and Microbiology" of the Ministry of Health of Belarus. A conclusion on the expressed biological activity of fabrics of optimal composition with respect to St. an. and Es. coli was received. The antimicrobial effect remains after 5 dry cleanings of samples. The method of samples contamination (infection) with testing microbes has conclusively demonstrated antibacterial and antifungal activity of fabrics.

Experts of the Central Scientific Research Institute for Complex Automation of Light Industry (JSC TSNIILKA, Moscow) established that the optimal composition of fibrous textile with bioprotective capability is as follows (\% by mass): natural and/or chemical fibers $-70 \div 95$, biologically active fibers $-5 \div 30$ [47].

\section{FIBERS WITH ANTIMICROBIAL PROPERTIES}

Products made of antimicrobial fibers have found their niche in the market of the new generation textiles. The demand for them continues to grow which has resulted in the change of priorities in textile products consumption. So, the demand for fibers with antimicrobial activity has respectively grown. The demand of Western European countries in these products in 2005 amounted to 17.6 thousand tons, in $2010-28$ thousand tons. In Russia, this value is close to 15 thousand tons [48].

World's leading textile companies have been manufacturing antimicrobial chemical fibers for more than 20 years. Trevira (Germany) has developed polyether fiber of Trevira Bioactive brand. The antibacterial effect is achieved by volumetric chemical and physical modification of fibers that provides for long-term retention of the effect even after 100 washings. Trevira Bioactive creators claim 
that the fiber protects the person against all forms and types of bacteria, thus ensuring purity and safety of the textile fabric. The fiber can be used in a range of applications, including production of workwear, overalls, aprons, trousers and shirts worn by medical personnel, food industry employees, etc. [49].

International company Nylstar (Italy) introduced bacteriostatic polyamide fibers Meril®Skinlife. They impart long-term antiseptic effect to the textiles without causing adverse reactions to a person. Such fibers are used in production of cloths and fabrics, including medical and filter ones. The technology of antiseptic modification is based on introduction of a silverbased bactericidal agent into the surface layer [50].

Amicor $\AA$, the fiber developed by Schoeller Bregenz, is considered to be an achievement in the field of bactericidal materials. This is a polyacrylonitrile fiber with antimicrobial agent triclosan. The technology of its production constitutes the company's trade secret. Fibers are used as a part of fabrics for production of sportswear, hosiery, as well as for production of linen and special purpose fabrics, lining materials [51].

Polypropylene fibers Prolen $\AA$ (manufactured by JSC Chemosvit Fibrochem) containing a silver-based bactericidal agent are intended for production of fabrics, knitted goods and non-woven fabrics. Textile products with the "Sanitized" logo have appeared in the European market. This marking means that antimicrobial Sanitized ${ }^{\circledR}$ fibers manufactured by Clariant Co. were used in manufacturing of the product [52].

Also of interest is Mirawave fiber introduced by Huvis Corporation (South Korea). These polyether staple fibers have the ability to emit infrared radiation and, due to this, display long-term antibacterial activity. ABF polyether fiber suppresses the development of microorganisms owing to the bactericidal agent being part of it [53].

DAK Americas Co has introduced the antimicrobial polyether staple fiber with the adjustable level of hygroscopicity under "Deleron Hydro Pur" brand [50]. The fiber comprises an antibacterial agent under the trade name "Alpha San" and ion exchange resin based on zirconium and silicon phosphates containing silver which inhibits the growth of microorganisms.

A range of products available on the Western European market of antimicrobial fibers is presented in Table 4.

Range of synthetic bactericidal fibers $[49,50,54]$

Table 4

\begin{tabular}{|l|l|l|l|}
\hline \multicolumn{1}{|c|}{ Manufacturer } & \multicolumn{1}{|c|}{ Trademark } & \multicolumn{1}{|c|}{$\begin{array}{c}\text { Material } \\
\text { fibers }\end{array}$} & \multicolumn{1}{|c|}{$\begin{array}{c}\text { Antibacterial } \\
\text { additive }\end{array}$} \\
\hline Accordis Kelheim GmbH, Germany & Danufil & Viscose & Triclosan \\
\hline Lenzing AG, Austria & Lenzing Viscosa & Viscose & Silver \\
\hline Montefibre SpA, Italy & Terital & PET & Silver \\
\hline R. Stat SA, France & $\begin{array}{l}\text { R. Stat P, } \\
\text { R. Stat N }\end{array}$ & $\begin{array}{l}\text { PET, } \\
\text { PA }\end{array}$ & Silver \\
\hline Accordis Acrylic Fibres UK Ltd. & Courtek M, & $\begin{array}{l}\text { PAN } \\
\text { PANicor }\end{array}$ & Triclosan \\
\hline Clariant, Switzerland & Sanitized & & Triclosan \\
\hline Noble Fiber Technologies & X-Static & PA/PET & Silver \\
\hline Saniwear & Terital, Leacril & PET, PAN & Silver \\
\hline Kanebo & Livefresh & PA & Silver \\
\hline Rhovyl & Rhovyl & PVC & Triclosan \\
\hline
\end{tabular}

Research institutes of Russia and Eastern Europe are also engaged in development of antimicrobial materials. So, the Slovak ScientificResearch Institute of Chemical Fibers has obtained polypropylene-based fibers resistant

to the action of microorganisms and mold which are used in the productions of textiles and for medical purposes. The Institute of Chemical Fibers (Poland) conducts researches on the use of chitin/chitosan as additives to bactericidal fibers. Moscow State University of Design and Technology together with the All-Russian Center of Disaster
Medicine "Zaschita" ("Protection") develop antimicrobial materials for medical use. Katamin $\mathrm{AB}$, as well as a compound comprising potassium iodide and naphthalene sulphonate (in addition to katamin) are used as the antimicrobial agent [55].

A.N. Kosygin Moscow State Textile University together with the Institute of Synthetic Polymeric Materials (Tver, Russia) has developed a method to impart bactericidal properties to viscose fibrous material by impregnation Polyhexamethyleneguanidine hydrochloride (metacide) which has low toxicity, prolonged effect 
and is a cationic surface-active substance is used as the bactericidal agent [56].

In certain cases, manufacturers of antimicrobial fibers report what active additives are introduced into the polymer base, but far more often they do not provide such information trying to protect their know-how;

however, in recent years they usually name a group of substances to which the additive belongs to show the consumer that fibers do not contain substances hazardous to health. Since suppression of the activity of microorganisms is not a sole requirement to the antimicrobial component of synthetic fibers, it is reasonable to consider the full range of such substances and to define criteria which they should meet.

\section{ANTIMICROBIAL FIBERS' USE IN MEDICINE AND CLOTHING}

Textile materials and products that have been engineered to meet particular needs are suitable for any medical and healthcare application in which a combination of strength, flexibility, and sometimes moisture-and air-permeability is required. Materials used include monofilament and multifilamenl yarns, woven, knitted, and non-woven fabrics, and composite structures. The applications are many and diverse, ranging from a single-thread suture to the complex composite structures used for bone replacement, and from the simple cleaning wipe to the advanced barrier fabrics used in operating rooms [57].

Over the last few years, the textile industry has developed different methods for obtaining fabrics and fibers with an antimicrobial action for use in hospital environments and for other purposes [16]. With the growing public health awareness of the pathogenic effects, malodors and stain formations caused by microorganisms, there is an increasing need for antibacterial materials in many application areas like medical devices, health care, hygienic application, water purification systems, hospital, dental surgery equipment, textiles, food packaging, and storage [58-60].

Various groups of antimicrobial substances belonging to the classes of organic and inorganic compounds are applied with the aim to create biologically active textile materials with widespectrum antimicrobial activity and resistance to different processing methods. The most common of them are metals and their salts, salts of quaternary ammonium bases, phenolic compounds, various heterocyclic compounds, including nitrofuran class compounds, antibiotics, antimicrobial dyes, etc.

The following antibiotics are also used to impart bactericidal properties to textile materials: cephalosporin, tetracycline, etc. Clinical studies of antibiotics have shown that the gram-positive and gram-negative microflora, including the colon group of bacteria, olms, blue pus bacillus, is sensitive to them [61].

The common carriers of antimicrobial materials are fabrics made of cellulose fibers manufactured by simple interlacing with smooth homogeneous surface. Among cellulose fabrics, the fabrics with chemically-bonded antimicrobial agents which are characterized by ability to retain the long-lasting bactericidal effect after repeated washings, sterilizations, autoclave treatment, etc. are of the greatest interest to medicine. For this purpose, cellulose is subjected to preliminary treatment in order to introduce (into the macromolecule) the reactive functional groups capable to interact with bactericidal or fungicidal preparations.

Antimicrobial fabrics made of cellulose fibers are used in production of medical bandages, tissues, sanitary products, underwear and bed-linen, hosiery, sock liners, as well as protective workwear for persons dealing with dangerous pathogens, plague, anthrax, brucellosis, etc. [58].

Wound dressings intended to accelerate healing of septic wounds and burns which application reduces the term of their treatment by half have been created on the basis of modified cellulose with reactionary active groups of medicinal substances [62].

Tissues made of low-grade cotton raw materials with surface density of 120-170 g/m and content of antimicrobial, antifungal or deodorizing additive of $10-70 \%$ of the mass of the material are related to sanitary products which are used for domestic and industrial purposes.

Medical bandages representing a sterile cotton gauze or similar textile material with a pharmaceutical carrier in the form of an ointment, paste, aerosol, etc. have found application in treatment of ulcers of the patients confined to bed. For example, a bandage on the base of a plain-woven cotton fabric and a layer of medicinal substances reduces microbial contamination of human skin and interrupts the mechanism of infectious diseases transmission [63].

The cotton-fabrics-based hosiery and sock liners have a distinctive mycocide effect resistant to repeated washings. They are applied for treatment and prevention of skin diseases.

Artificial and synthetic fibers and threads are effective carriers of antimicrobial preparations. So, fabrics made of polyvinylalcohol, polyethylenterephthalat, ftorlon, hydrocellulose and acetate fibers and threads are obtained by introducing various bactericidal agents into a spinning solution or polymer melt. However, they lack the antimicrobial effect resistance to repeated washings. Therefore, such fabrics can be used for the products designed for a limited number of washings or intended to be 
used under conditions where they are not subjected to processing with water. However, as discussed in this chapter, the antimicrobial polyester fibers produced by the crazing technology can endure repeated wet processing with practically no decrease in antimicrobial activity.

Antimicrobial fabrics from polyvinyl alcohol, polyacrylonitrile, polyamide threads are used, for example, to produce sanitary products, hosiery, as well as rugs for hospitals.

Antimicrobial synthetic threads have a wide application in the form of suture materials - threads. Such surgical suture represents a new pharmaceutical form of chemotherapeutic preparations to prevent side effects on the human body and tissues which frequently occur when traditional methods of medicines administration are used. According to data of the A.V. Vishnevsky Institute of Surgery (Russia), polypropylene and polycaproamide suture threads possess the highest and prolonged therapeutic action among all known antimicrobial suture materials. Synthetic threads with antimicrobial properties are also used as vascular implants.

Besides the fabrics, knitted cloths have found application as textile carriers for antimicrobial materials. The knitted cloth (unlike the fabrics) possesses good flexibility, elasticity and stretchability that allows to obtain products in the form of tubes of various diameters and shapes. The type of the knitted material weaving is one of the main characteristics which defines its properties: stretchability, unknitting, shape stability, etc. Knitted cloths with the main types of weaves (jersey structure, rib structure, tricot, etc.) are widely used in medicine.

Knitted fabrics based on polyester and polyamide threads, as well as spindleless spinning cotton yarn with surface density of $140-280 \mathrm{~g} / \mathrm{m}$ are used to produce dressing materials [64-66]. They possess high capillary action, lightness and can be freely separated from the wound surface. High shape stability at washing and resistance to sterilization allow the reuse the products made of knitted synthetic materials (up to 10 times).

Knitted fabrics made of synthetic threads, for example, polyester ones, can be used in the bandaging products as an atraumatic layer [67].

Cotton knitted materials with a complex of therapeutic and antimicrobial substances are applied in medical bandages and tissues. They rapidly absorb wound secretions, possess the expressed antimicrobial properties, are characterized by the increased therapeutic effect, provide for dynamic clearing of infected wounds, prolonged medical action and less frequent change of bandages at practically complete atraumaticity.

For example, AKTIVTEKS antimicrobial bandages and tissues made of cotton knitted fabric are designed for treatment of trophic ulcers and ulcerous defects at diabetic foot infections. They contain medicinal agents of local anesthetic, antiseptic and wound-healing action along with a biocompatible polymer-polysaccharide which swells when moistened and forms a gel, thus ensuring a prolonged introduction of medicines into the wound. Application of AKTIVTEKS tissues increases the efficiency of trophic ulcers treatment because of the fact that, at the first stage, combination of antioxidant and antimicrobial action leads to the improved medical outcomes, while, at the second stage, the combination of antimicrobial and wound-healing action leads to reduction of the healing time [68].

Cotton-lavsan knitted fabrics with antimicrobial properties are used as medical swabs and surgical bandages. They are elastic, can be easily placed on contoured surfaces of wounds and introduced into slit-like wounds (as well as easily and relatively painlessly removed from them); they possess high hygroscopicity and capillarity and ensure drainage (the most important factor of treatment for wound) while their basic properties are as good as the ones of the medical gauze swabs and bandages. The design of products (knitted weaving, plain edge) simplifies operation of cotton-lavsan swabs and excludes the possibility to leave the tiniest threads of dressing material in the wound which is often the case when gauze swabs are used [69].

Flat knitted mesh cloths made of antimicrobial polypropylene threads have been successfully used in reconstructive surgery for many years, while mesh knitted fabrics made of polypropylene threads in combination with polyamide ones are used (instead of gauze tissues) as antimicrobial dressing for burn wounds [70].

Non-woven cloths are promising carriers of antimicrobial preparations. Non-woven fabrics obtained by needle-punching and canvas-sewing techniques, thermal bonding, adhesive bonding or their combinations are the most widespread ones.

Needle-punched non-woven fabrics made of polypropylene fibers with surface density of 100 $\mathrm{g} / \mathrm{m}^{2}$ and higher, as well as the ones based on polyvinylalcohol fibers with chemically bonded antimicrobial agents have found application as biologically active swabs [71]. Since polypropylene fibers have cation- and anion-exchange groups and medicinal agents have basic or acid groups of different ionic strengths, it is possible to control the bonding strength between the two which accordingly provides for the possibility to obtain biologically active non-woven fabrics with variable time of therapeutic action.

Medical non-woven material in the form of threadless canvas-sewn cloth made of the bleached modified viscose is used for bandages. It possesses high hygroscopicity, it rapidly absorbs and effectively withdraws the secretions from wounds. Air permeability of a bandage made of such non- 
woven cloth is 4 times higher as compared to a cotton gauze bandage.

Thermally-bonded non-woven fabrics made of polyurethane threads are used to produce elastic bandages. Along with high elasticity, they possess good air permeability.

The problem of textile materials "dusting" prevention in surgery has been one of the most important challenges for a long time. Particles of fibers (when they get into an open wound) often lead to granulomas. The use of polypropylene non-woven materials with latex binders reduces the amount of large (more than 3 microns) particles in the wound by $90 \%$ as compared to cotton fabrics. They are used to produce tissues and sanitary products.

Thus, fabrics, knitted fabrics and non-woven cloths are the main textile carriers of antimicrobial materials used in medical practice.

Fabrics and knitted fabrics are used widely enough in production of clothes, linen, surgical dressings, sanitary and other products. Non-woven cloths are not commonly used yet and have come into use mostly as surgical dressings. However, nonwoven antimicrobial fabrics start to be used for production of workwear and bedding items, but most often such products are single-use ones.

Antimicrobial materials used to manufacture medical wear, including special clothes for surgeons, occupy an important place. Such clothing not only provides for reduction in postoperative pathologies, but also protects the surgeon against infections which is particularly relevant with regard to the spread of such diseases as AIDS.
At present, products obtained from woven and knitted textile cloths prevail in the assortment of medical products based on textile antimicrobial materials. Non-woven cloths are used in production of antimicrobial materials on a limited basis. Antimicrobial materials on non-woven carriers are used mainly for production of single-use surgical dressings, bandages, tissues, sanitary products, personal hygiene products, medical workwear and linen (bed-linen, underwear, surgery clothes) [68].

\section{Conclusion}

The problem of preserving textile materials quality and consumer properties is of great practical importance and a task which solution lies at the intersection of sciences. Adverse changes in textile fabric properties during transportation, storage and operation are caused by the damages due to physical, chemical, mechanical and biological factors. Biological deterioration is the main cause of impairment in textile materials quality and in some cases of their complete destruction. Methods of textile protection from biodeterioration are used at different stages of usage and consumption of textile goods, as well as during their manufacturing. This review is devoted to polyester fibers with antimicrobial properties and describes the antiseptic components of fibers, testing methods and fiber's properties. The final part shows numerous examples of application of antimicrobial fibers (natural and synthetic ones) in medicine and clothing.

\section{References:}

1. (1992) Russian State Standard (GOST) 9.10291. Unified system of corrosion and ageing protection. Influence of biological factors on technical objects. Terms and definitions. Moscow, 1992

2. (1985) Biotechnology: Principles and Applications (Studies in Microbiology, Vol. 3). Higgins, I.J.; Best, D.J.; Jones, J. (Editors). Oxford Uni., 1985

3. Pehtasheva EL, Neverov AN, Sinizin NM (2002) Die rolle und nutzung mikrobiologischer prozesse im lebenszyklus von materialien unter besonderer berucksichtigung von textilien. Forum Ware, 2002, Bd. 30, No 1-4, p. 73-76.

4. Sklyannikov VP (1982) Consumer properties of soft goods. Moscow: Ekonomika, 1982, 160 p.
5. Khasanov GI (2002) To the problem of wool destruction by microorganisms. Textile industry, 2002, No 2, p. 29-30.

6. Mesyachenko VT, Kokoshinskaya VI (1987) Merchandising of soft goods. Moscow: Ekonomika, 1987, 415 p.

7. Pekhtasheva El (2002) Biodeterioration and protection of nonfoods / Ed. A.N. Neverov. Moscow: Masterstvo, 2002, 224 p.

8. Afinogenov GE, Panarin EF (1993) Antimicrobial polymers. S.-Petersburg: Gippokrat, 1993, 264 p.

9. (1980) Fibers with special characteristics / Ed. L.A. Wolf. Moscow: Khimiya, 1980, 240 p.

10. Goldade VA, Pinchuk LS, Vinidiktova NS (2010) Modification of polyester fibers by bactericides using crazing mechanism. Intern. 


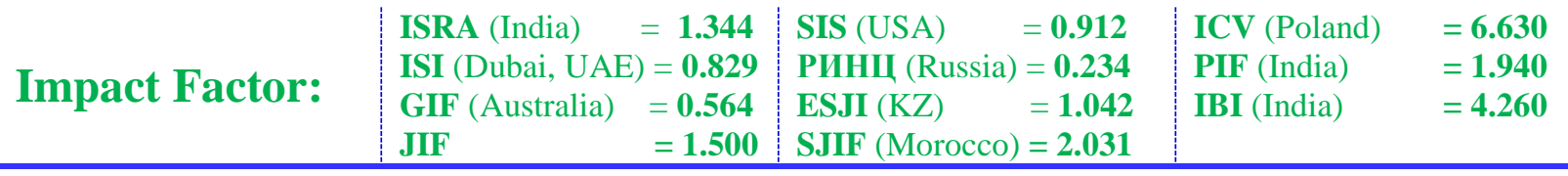

Polymer Processing, 2010, Vol. 25, No 3, p. 199-204.

11. Krasil'nikov AP (1995) Handbook on antiseptics. Minsk: Vysheishaya shkola, 1995, $366 \mathrm{p}$.

12. (1987) Antimicrobial materials in medicine. Ed. by L.A. Il'in. Moscow: Medicine, 1987, 190 p.

13. Pyatkin KD, Krivoshein YS (1981) Microbiology. Moscow: Medicine, 1981, 512 p.

14. Cho KH, Park JE, Osaka T, Park SG (2005) The study of antimicrobial activity and preservative effects of nanosilver ingredient. Electrochimica acta, 2005, V. 51, No 5, p. 956960.

15. Miyanaga S, Hiwara A, Yasuda H (2002) Preparation and high bacteriostatic action of the activated carbons possessing ultrafine silver particles. Science and Technology of Advanced Materials, 2002, Vol. 3, No 2, p. 103-109.

16. Mariscal A, Lopez-Gigosos RM, Carnero-Varo M, Fernandez-Crehuet J (2011) Antimicrobial effect of medical textiles containing bioactive fibers. Eur J Clin Microbiol Infect Dis., 2011, Vol. 30(2), p. 227-232. DOI: 10.1007/s10096010-1073-1. Epub 2010 Oct 17

17. Nomiya K, Onoue KI, Kondoh Y, et al. (1995) Synthesis and characterization of oligomeric, anionic thiomalato-silver(I) complexes with biological activities. Polyhedron, 1995, Vol. 14, No 10, p. 1359-1367.

18. Zaporojtchenko V, Podschun R, Schürmann U, et al. (2006) Physico-chemical and antimicrobial properties of co-sputtered $\mathrm{Ag}-$ $\mathrm{Au} / \mathrm{PTFE}$ nanocomposite coatings. Nanotechnology, 2006, Vol. 17, No 19, p. 4904-4908.

19. Chen CY, Li Chiang C (2008) Preparation of cotton fibers with antibacterial silver nanoparticles. Materials Letters, 2008, Vol. 62, p. 3607-3609

20. (2017) Nexera Medical. Strategic Alliances. Available:

http://www.nexeramed.com/cfiles/about_partne rs.php\#agion (Accessed: 10.03.2017).

21. Kazakyavichute GA, Korchyagin IV, Kul'kova ON, Sedov AV, Il'in VV (1983) Imparting antimicrobial properties to cellulose textile materials. Textile Industry, 1983. No 9, p. 5355.

22. Borisevich IV, Sytsko VE, Pinchuk LS (2005) Active components of bactericidal polymer fibers. Plasticheskie massy (Plastics Magazine), 2005, No 8, p. 35-40.

23. Borisevich IV, Sytsko VE, Pinchuk LS, Ignatovskaya LV (2005) Antimicrobial components of polymer fibers. Materials. Technologies. Tools, 2005, Vol. 10, No 3, p. 63-68.
24. Pletnev YN (1990) Cosmetics-hygienic cleaning agents. Moscow: Khimiya, 1990, 272 p.

25. Ernandes E (2000) Triclosan: modern conceptions. Cosmetics and Medicine, 2000, No 1, p. 5-17.

26. Efimov KM, Gembitskiy PA, Snezhko AG (2000) Poliguanidins - class of low-toxicity disinfectant agents with prolonged action. Disinfectant art, 2000, No 4, p. 22-30.

27. Regos J, Zak O, Solf R (1979) Antimicrobial spectrum of triclosan, a broad-spectrum antimicrobial agent for topical application. Dermatologica, 1979, Vol. 158, No 1, p. 72-79.

28. Allmyr M, Adolfsson-Erici M, McLachlan MS, Englund GS (2006) Triclosan in plasma and milk from Swedish nursing mothers and their exposure via personal care products, Science of the Total Environment, 2006, Vol. 372, p. 87-93

29. Zafar AB, Butler RC, Reese DJ (1995) Use of 0.3 triclosan (Bacti-Stat) to eradicate an outbreak of methicillin-resistant Staphylococcus aureus in a neonatal nursery. American $J$. Infect. Control, 1995, Vol. 23, No 3, p. 200208.

30. Kiaerheim V, Barkvoll P, Waaler SM, Rolla G (1995) Triclosan inhibits histamine-induced inflammation in human skin. J. Clin. Periodontol, 1995. Vol. 22, N 6, p. 423-426.

31. (1977) Micellization, Solubilization and Microemulsions. Ed. K.L. Mittal. New York: Plenum Press, 1977, 489 p.

32. (2011) Russia patent $2,421,555$. D01D 5/247. Process of antimicrobial PET fibers manufacturing. L.S. Pinchuk, N.S. Vinidiktova, V.A. Goldade, et al., 2011.

33. (2011) Belarus patent 15,252. D01D 5/247. Process of antimicrobial PET fibers manufacturing. L.S. Pinchuk, N.S. Vinidiktova, V.A. Goldade, et al., 2011.

34. (2009) Belarus patent 12,186. D01F 6/92, D06M 13/00. Process of antimicrobial PET fibers manufacturing. L.S. Pinchuk, V.A. Goldade, N.S. Vinidiktova, et al., 2009.

35. (2008) Belarus patent 11,260. D01F 6/92, D06M 11/00. Process of manufacturing antimicrobial fibers from polyethylene terephthalate. L.S. Pinchuk, V.A. Goldade, N.S. Vinidiktova, et al., 2008.

36. (2008) Belarus patent 10,803. D01F 6/92, D06M 13/00. Process of manufacturing polyethylene terephthalate antimicrobial fibers. L.S. Pinchuk, V.P. Novikov, N.S. Vinidiktova, et al., 2008.

37. (2011) Belarus patent 13,983. D01F 6/92, D06M 11/00. Process of manufacturing bactericidal fibers from polyethylene terephthalate. L.S. Pinchuk, V.P. Novikov, N.S. Vinidiktova, et al., 2011. 
38. (2011) Belarus patent 14,166. D01F 6/92, D06M 11/00. Process of attachment antimicrobial activity to PET fibers. L.S. Pinchuk, V.P. Novikov, N.S. Vinidiktova, et al., 2011.

39. (2010) Russian patent 2,400,576. D01F 6/92, D06M 11/00, D01D 5/247. Process of attachment antimicrobial activity to PET fibers. L.S. Pinchuk, V.P. Novikov, N.S. Vinidiktova, et al., 2010.

40. (2010) Belarus patent 6,040 (utility model). G01N 3/00. Device for crazing investigation in chemical fibers. L.S. Pinchuk, N.S. Vinidiktova, V.A. Goldade, et al., 2010.

41. Vinidiktova NS, Borisevich IV, Pinchuk LS, et al. (2006) Modification of PET fibers with bactericides by craising mechanism. Fiber Chemistry, 2006, No 5, p. 34-37.

42. (2009) STB ISO 6330-2009 Textile materials. Washing and drying methods, applied for testing textiles. Minsk: BelarusLows, 2009, 24 p.

43. Vinidiktova NS, Pinchuk LS, Goldade VA, Novikov VP (2009) Craising use for antimicrobial fibers manufacturing. Doklady NAN Belarusi (Reports of NAS of Belarus), 2009, Vol. 53, No 5, p. 108-112.

44. (2003) Technology creation and production organization of fire-, bio- and electro-protective chemical fibers using crazing technology. Textile, 2003, Vol. 6, No 4, p. 32-33.

45. Vinidiktova NS, Pinchuk LS, Goldade VA, et al. (2009) Production of antimicrobial chemical fibers using crazing technology. Materialovedenie (Material science). 2009, Vol. 151, No 10, p. 57-63.

46. Gorodnicheva NA (2003) Investigation of specific properties of textile carriers with antimicrobial fibers. Proc. of Intern. Conf. "Polycomtrib". Gomel, 2003, p. 62-64.

47. (2012) Russian patent 2,439,221. D03D 25/00. Textile fibrous material with bioprotective properties. T.N. Kudryavtseva, V.A. Grischenkova, L.S. Pinchuk, V.A. Goldade, 2012.

48. (2003) Kudryavtseva T.N. Priorities in development of the complex on manufacture and processing of polyether fibers in Russia. LegPromBiznes-Direktor, 2003, Vol. 55, No 5, p. 29-31

49. Papkov CP (1990) Theoretical grounds of chemical fibers manufacturing. Moscow: Khimiya, 1990, 272 p.

50. Koluntayev S, Ulanov K (2003) Thank you, Meril. The bacteria are stepping back. Rynok legkoi promyshlennosni (The market of light industry), 2003, No 28, p. 14-15.
51. Il'ina I (2003) Today knitted wear is not only comfort but also protection! Technical textile, 2003, No 5, p. 27-28

52. Bossard M (2002) Hygienic protection of textile materials as an argument for goods sailing. An example of high marketing. Russian Chemical Journal, 2002. Vol. XLVI, No 2, p. 62-65.

53. Perepelkin KE (2001) Physical-chemical nature and structural conditionality of unique properties of polyether fibers. Chemical fibers, 2001, No 5, p. 8-19.

54. Aizenshtein EM (2003) Russian market of imported polyether fibers. Textile Industry, 2003, No 9, p. 60-63.

55. Makarova NA, Buzov BA, Mishakov VY (2003) Textile against microbes. Nomenclature and quality of carriers of antimicrobial preparations. Textile Industry, 2003, No 6, p. 20-21.

56. Yudanova TN, Skokova IF, Bochkareva ON, Gal'braikh LS (2001) Pharma-kinetical properties of fibrous materials modified by biological active matters of different type. Chemical Fibers, 2001, No 4, p. 35-39.

57. Rigby AJ, Anand SC, Horrocks AR (1997) Textile Materials for medical and healthcare applications. J. Text. Inst., 1997, Vol. 88, Part 3, p. 83-93.

58. Shahidi S, Ghoranneviss M, Moazzenchi B, Rashidi A, Mirjalili M (2007) Investigation of antibacterial activity on cotton fabrics with cold plasma in the presence of a magnetic field. Plasma Process and Polymers, 2007, Vol. 4, p.1098-1103;

59. Anand SC, Kennedy JF, Miraftab M, Rajendran S (2010) Editors. Medical and Healthcare Textiles. Elsevier, Cambridge, 2010, 529 p. ISBN: $\quad 978-1-84569-224-7, \quad$ Available: http://www.bolton.ac.uk/IMRI/Staff/StaffPages/ ProfSubbiyanRajendran.aspx\#sthash.YoLVKIg X.dpuf. (Accessed: 10.03.2017).

60. Anand SC, Kennedy JF, Miraftab M, Rajendran S (2006) Editors, Medical Textiles and Biomaterials for Healthcare, 1-508, Cambridge, Woodhead Publishing Limited, ISBN 185573 683 7, Washington DC, CRC Press, ISBN 084931780 0, 2006.

61. Chao Dong, Li-Ying Qian, Guang-Lei Zhao, Bei-Hai He, Hui-Ning Xiao (2014) Preparation of antimicrobial cellulose fibers by grafting $\beta$ cyclodextrin and inclusion with antibiotics. Materials Letters, 2014, Vol. 124, p. 181-183.

62. (2000) Russian patent 2157244. A61L 15/44. Method of manufacturing material with antimicrobial properties. Ponedel'kina I.Yu., Sibagatullin N.G., Gataullin N.G., et al., 2000.

63. (1998) Russian patent 1,473,147. A61L 17/00. Method of manufacturing suture filament with antimicrobial properties. Plechev V.V., 1998. 


\begin{tabular}{l|lrl|l|ll} 
& ISRA (India) & $=\mathbf{1 . 3 4 4}$ & SIS (USA) & $=\mathbf{0 . 9 1 2}$ & ICV (Poland) & $=\mathbf{6 . 6 3 0}$ \\
Impact Factor: & ISI (Dubai, UAE) $=\mathbf{0 . 8 2 9}$ & PUHL (Russia) $=\mathbf{0 . 2 3 4}$ & PIF (India) & $=1.940$ \\
& GIF (Australia) & $\mathbf{0 . 5 6 4}$ & ESJI (KZ) & $=\mathbf{1 . 0 4 2}$ & IBI (India) & $=\mathbf{4 . 2 6 0}$ \\
& JIF & $\mathbf{1 . 5 0 0}$ & SJIF (Morocco) & $=\mathbf{2 . 0 3 1}$ & & \\
\hline
\end{tabular}

64. (2002) Russian patent 2,189,210. A61F 13/15, A61F 13/40, A61L 15/44, A61P 17/02. Multilayer medical bandage. Boldyrev S.N., 2002.

65. (1996) Russian patent 2,101,033. A61L 15/22. Dressing material with prolonged medical action. Boldyrev S.N., 1996.

66. (2002) Russian patent 2,178,310. A61K 45/06, A61L 15/20, A61L 15/28, A61P 17/02. Method of treatment ulcerous defects at syndrome of diabetic foot. Dreval A.V., Bakharev I.V., Krivikhin V.T., Vasil'eva T.S., 2002.

67. (2002) Russian patent 2,178,311. A61L 15/20, A61L 15/28. Method of treatment trophic ulcer of venous genesis. Batkaev E.A., Svetukhin A.M., Askerov N.G., et al., 2002.
68. Vainburg VM, Shtyagina LM, Illarionova EL, Chufarovskaya TI (2003) Biological active materials. Technical Textile, 2003, No 6, p. 2426.

69. (1995) Russian patent 2,044,549. A61L 15/16. Bandage for treatment infected wounds and rendering first aid. Adamyan A.A., Zakharov V.V., Malinin S.E., et al., 1995.

70. (2000) Russian patent 2,143,281. A61L 15/16, A61L 15/44. Bandage for treatment wounds, burns, wounds, bedsores and rendering first aid. Shklyar S.A., Mokrushin I.N., 2000.

71. (1988) US patent 4,748,076 A. A61F 13/18, A61L 15/00. Water absorbent fibrous product and a method of producing the same. Kazuo Saotome, 1988. 